\title{
Mineralium Deposita: change and continuity
}

\author{
Georges Beaudoin • Bernd Lehmann
}

Received: 16 October 2012 / Accepted: 19 October 2012 / Published online: 25 October 2012

(C) Springer-Verlag Berlin Heidelberg 2012

2012 has been a year of transition for Mineralium Deposita. After 4 years as co-editor, Patrick J. Williams has stepped down in June to fully concentrate on his consulting business. During Patrick's tenure, Mineralium Deposita has continued to grow as a top journal for research on mineral deposits. We are grateful for his dedicated work and wish him the best of luck for the future.

The Council of the Society for Geology Applied to Mineral Deposits (SGA) has appointed Georges Beaudoin from Université Laval (Québec, Canada) as the new coeditor of the journal. Georges has been on the Editorial Board since 2001. Bernd Lehmann from Technische Universität Clausthal (Clausthal, Germany) remains as co-editor. Three new associate editors joined the Editorial Board in 2012. These are David Craw (University of Otago, Dunedin, New Zealand), Albert Gilg (Technische Universität München, Munich, Germany), and Robert Linnen (Western University, London, Canada). Associate editor Noel C. White has stepped down after many years of service, and we thank him for his energic and careful work.

The journal continues to attract a high level of submissions of about 120-140 papers per year. Since 2011, a Mineralium Deposita volume contains about 1,000 printed pages, with color print free of charge to all authors. We have a wide distribution across the world. Through subscriptions and more than 300 online deals with aggregators and consortia, Mineralium Deposita is accessible to more than 7,700 institutions worldwide. This is a strong incentive to submit research to Mineralium Deposita and to gain large exposure. The world of scientific publishing is changing quickly, and direct download of papers published in Mineralium Deposita has grown

G. Beaudoin $(\bowtie)$

Université Laval,

Québec, G1V 0A6 QC, Canada

e-mail: beaudoin@ggl.ulaval.ca

B. Lehmann

Technishche Universität Clausthal,

Clausthal, Germany from about 98,000 in 2008 to 133,000 in 2011, for an annual rate of increase of approximately $10 \%$. Approximately $20 \%$ of downloads are for papers published Online First and for the calendar year, whereas about $60 \%$ of downloads are for papers published since 1997. Roughly $44 \%$ of downloads are from the Asia-Pacific region (China, $18 \%$; Australia, $10 \%$ ), whereas Europe accounts for $28 \%$ (Germany, $6 \%$; UK, $4 \%$ ), North America for $16 \%$ (USA, $8 \%$; Canada, $7 \%$ ), and both Africa and South America each account for $6 \%$.

As editors of Mineralium Deposita, we are committed to diligent review of submissions. In 2011, the average time from submission to acceptance, including author corrections of revised versions, was 217 days, slightly down from 239 days in 2010. However, this distribution is highly skewed, and most papers were handled within 150 days. After acceptance, a paper is published online with a DOI within approximately 3 weeks. This ensures rapid publication and allows the new papers to be read, downloaded, and cited immediately, such that your work reaches the scientific community quickly. The research submitted to Mineralium Deposita is sourced from a large number of countries with top contributors, in 2011, being China (30), Canada (15), and Australia (11). As we wish to ensure high scientific quality, we accept, on merit, approximately $40 \%$ of the submissions from year to year. Since 2006, the annual impact factor (IF) of Mineralium Deposita has varied between 1.25 and 2.06, with a value of 1.68 in 2011, close to the average 10-year IF of 1.66 . We are dedicated to publish high-quality, innovative, and challenging papers in Mineralium Deposita, and we work to improve the standing of the journal. The two most cited papers to date, published in Mineralium Deposita in 2010, were by R.R. Keays and P.C. Lightfoot on the crustal sulfur contamination that causes formation of magmatic $\mathrm{Ni}-\mathrm{Cu}$ sulfide deposits (Keays and Lightfoot 2010) and by N. Koglin, H.E. Frimmel, W.E. Lawrie Minter, and H. Braetz on the trace element composition of pyrite from Mesoarchean and Paleoproterozoic placer deposits (Koglin et al. 2010). 
Every 2 years, the SGA grants its Best Paper Award at its Biennial Meeting, based on recommendation of the Editors of Mineralium Deposita. The 2011 Best Paper Award, for papers published in Mineralium Deposita volumes 45 and 46, has been attributed to H. Murakami, J.H. Seo, and C.A. Heinrich for their paper discussing the relation between the $\mathrm{Cu} / \mathrm{Au}$ ratio and depth of formation of porphyry $\mathrm{Cu}-\mathrm{Au} \pm \mathrm{Mo}$ deposits (Murakami et al. 2010).

You can receive the Table of Contents (ToC) of each issue of Mineralium Deposita by email as soon as an issue is completed, before it is printed and mailed. Using ToC Alerts, you will receive an email from Springer, containing the table of contents of the issue and links to download the Mineralium Deposita papers. This is a service that is underutilized by our readers: to activate ToC Alerts, go to http://www.springer.com/126 and simply enter your email address. If you activate ToC Alerts, you will not receive other promotional email from Springer.

\section{References}

Keays RR, Lightfoot PC (2010) Crustal sulfur is required to form magmatic $\mathrm{Ni}-\mathrm{Cu}$ sulfide deposits: evidence from chalcophile element signatures of Siberian and Deccan Trap basalts. Mineralium Deposita 45:241-257

Koglin N, Frimmel HE, Lawrie Minter WE, Brätz H (2010) Traceelement characteristics of different pyrite types in Mesoarchaean to Palaeoproterozoic placer deposits. Mineralium Deposita 45:259-280

Murakami H, Seo JH, Heinrich CA (2010) The relation between $\mathrm{Cu} / \mathrm{Au}$ ratio and formation depth of porphyry-style $\mathrm{Cu}-\mathrm{Au} \pm \mathrm{Mo}$ deposits. Mineralium Deposita 45:11-21 